\title{
Library Security and the Federal Bureau of Investigation
}

\begin{abstract}
Elements in a security program for a library or archival institution are discussed, as well as action that can be taken when a theft does occur and the role of the Federal Bureau of Investigation. Some examples of problems encountered in the conduct of investigations and methods employed by thieves are also presented.
\end{abstract}

I WOULD LIKE TO DISCUSS THE PROBLEM of library and archival security from the standpoint of prevention, recovery of stolen items, successful prosecution of the thieves, and the assistance an institution can render to law enforcement agencies in carrying out their responsibilities. I would like to discuss also the official interest the Federal Bureau of Investigation has in thefts from libraries and archives.

\section{Library Security Programs}

Any consideration of theft prevention necessarily must deal with security programs and the responsibilities of personnel in our nation's libraries and archives. It is necessary that each institution maintain a reliable catalog of its books, archives, and manuscripts. Some libraries possess material of great value that they have not yet had an opportuni-

William J. Riley is a special agent in the General Investigative Division, Federal Bureau of Investigation, Washington, D.C. This article is based on an address given at the ALA Conference in July 1976 in a program, "Stealing the American Heritage: The Theft of Manuscripts from Libraries and Archives," presented by the Manuscripts Collections Committee, ACRL Rare Books and Manuscripts Section. ty to examine closely or to catalog. To preserve their security, such items should not be generally accessible. If access is granted, it should be done with the knowledge that these materials have not been properly cataloged and that closer scrutiny is required when users are allowed access to them.

Persons having access to library and archival materials should be required to provide proper identification, and each institution should maintain logs which accurately record those people granted access. The log should reflect the specific identification employed by the patron. Such a record forms an important part of a theft prevention program that should be established at each institution. Other useful elements in a security program include guard forces, a consistently alert staff, surveillance cameras, and limitations on access.

To buttress the security program, we suggest regular inventories of the more important items to be sure they are still present in the collection. To tighten charge-out procedures for certain items, institutions may wish to consider obtaining a fingerprint of the person to whom library and archival material is checked out. At the same time a receipt is obtained which recognizes the person's acceptance of responsibility for the tem- 
porary loan of the items. If budgets permit, cameras similar to those used when a check is cashed at a supermarket could be very helpful.

The logs that record the persons granted access to material should be kept for an extended period of time in the event any loss goes undetected. Such logs form an important body of records for investigating law enforcement agencies when it is determined that certain materials have been stolen. Many times these records are useful in the identification of the thieves and thus are valuable in later prosecution and recovery of stolen items.

\section{Related Problems and Solutions}

Frankly, one of the things that trouble law enforcement professionals about losses of valuable material from our nation's libraries, archives, and museums is that in many instances the stolen item can never be replaced. An example of this can be seen in one recent case. We determined several books by Shelley had been stolen from a West Coast college. FBI investigation resulted in the arrest of the person responsible and his conviction in a U.S. district court. One of the recovered volumes was an 1821 publication which had been given by Shelley to his associate, John Taaffe. The book, known in literary circles as the Taaffe edition of Shelley's Adonais, contained numerous annotations and commentary by Taaffe. Such a book is priceless, and its loss deprives scholars forever of the only avenue open to them to learn intimate details in the lives of such important persons. It is for this reason the FBI necessarily approaches the theft of such property in a prudent manner. We fully recognize the serious loss to the world of scholars of such material and make every effort to recover such stolen items in the exact condition they were in when taken.

Several problems arise in carrying out investigations dealing with stolen library and archival material. In many instances the nature of the stolen material requires an expert to positively identify it. The difficulty of identification and ease of transportation are factors that aid criminals. In this connection it is necessary for law enforcement agencies to have evidence admissible in a court of law to pinpoint specific ownership of the stolen items.

Other problems deal with identifying both thieves and persons to whom the stolen items may have been sold. A limited market certainly does exist for stolen historical records, manuscripts, and rare books. This in and of itself suggests that prompt dissemination of information concerning the theft can be of real assistance in locating stolen material. For example, prompt notice to similar libraries or archival repositories about the theft and identifying specific items allow other institutions to check like items in their custody.

The positive nature of such prompt dissemination was shown recently when Winslow Homer prints were discovered missing from several eastern colleges. After learning of the theft of prints from issues of Harpers Weekly in one library, other librarians learned some of their own prints had also been stolen.

Several years ago an ex-convict offered to sell a prominent southern art dealer a quarter of a million dollars worth of lithographs, books, and manuscripts. Unknown to the thief at the time the items were offered for sale, the expert recognized some of the books as identical to those stolen in the northeastern part of the country. The art dealer's cooperation with the FBI allowed us to arrest the thief, at which time lithographs, books, and manuscripts valued in excess of $\$ 120,000$ were recovered.

It would appear some of the very qualities that make for a successful librarian or archivist-namely, patience and imagination-lend themselves to 
implementing a successful security program. Persons in these professions must have the patience to search through reams of material in the course of their work, and they must have the imagination to know where to look. This patience and imagination can be useful when applied to an established security program aimed at shoring up defenses against potential thieves.

\section{When Theft Does Occur}

One problem facing an institution is what to do if property is being taken wrongfully and the librarian or archivist suspects that the thief has stolen items in his or her possession. Employees who have good reason to believe they have caught a person in the act of stealing are placed in a difficult position. They must either permit the suspected wrongdoer to walk out-and very possibly say goodbye to the stolen itemsor run the risk that they will be liable for heavy damages for any detention.

William L. Prosser, in his Law of Torts, advises that many courts have held such a person liable for false imprisonment even though an honest mistake has been made in detaining a suspected thief. The problem is a major one. We believe it is possible thefts take place each year when an institution employee is uncertain whether or not to detain the suspected thief for a short time in order to investigate.

In some states there have been a number of judicial decisions which permit a person who reasonably suspects a person of theft to detain, in good faith, the suspected individual for a short time in order to investigate. This seems entirely reasonable and justified by all ordinary usage, as among decent people an honest person might be expected to remain voluntarily to assist in clearing up such a matter. This privilege, however, is very restricted and confined to what is reasonably necessary for its limited purpose. The purpose, of course, would be to enable the employee to do what is possible on the spot to discover the facts. It appears there will be liability if the detention is for a length of time beyond that which is reasonable and necessary for such a short investigation.

Liability could also occur if the person detained is assaulted, insulted, or bullied, if a public accusation is made, or if the detention privilege is exercised in an unreasonable manner. This certainly would occur if the employee purports to make a definite arrest and take the person into legal custody or attempts to obtain a confession. These matters should be left strictly to law enforcement officials. In most court decisions the privilege apparently has been limited to detention on the premises where the theft has occurred and does not extend to areas where the thief may go after leaving the premises.

It behooves each institution to seek specific guidance from its attorneys and to establish a specific plan of action in cooperation with local police. Such a plan should be clearly understood by all employees so they know what to do if they have reason to believe items are being stolen.

\section{ROLE OF THE FBI}

Several laws under which the FBI has jurisdiction allow us to investigate certain thefts of library and archival material. The FBI is responsible for investigation of crimes wherein stolen property is transported interstate, but only if the property stolen is valued at $\$ 5,000$ or more. Such thefts are investigated under authority set out in Sections 2314 and 2315, Title 18, U.S. Code.

We also investigate fraud-by-wire violations under Section 1343, Title 18, U.S. Code, which prohibits the use of wire, radio, or television facilities in the execution of a fraudulent scheme. Such a violation might occur and has happened when thieves attempt to sell 
stolen library or archival material to an innocent purchaser in another state and use a telephone in an attempt to carry out their scheme. No dollar minimum need be involved under the Fraud by Wire Statute.

In those instances where the stolen archival or library material is the property of the federal government, the FBI would have jurisdiction under the Theft of Government Property Statute, outlined under Section 641, Title 18, U.S. Code. There is no minimum value in connection with this violation. Thefts from institutions located on U.S. government land could be investigated in connection with federal law which makes it a violation to commit certain crimes on a government reservation. This is covered in Section 661, Title 18, U.S. Code.

When none of these circumstances exist, the FBI can participate in a local investigation under a federal law known as Unlawful Flight to Avoid Prosecution. This federal violation makes it unlawful for a person to move or travel in interstate commerce with the intent to avoid prosecution. In those instances, if local authorities request FBI assistance in locating the thief, we can enter the case. The FBI will begin active investigation aimed at locating and arresting the person sought. Such a federal warrant would also give the FBI authority to seize stolen library or archival material taken by the wanted person.

\section{Methods EMPLOYEd By Thieves}

Recently it was possible for a thief to steal a four-volume set of Audubon's The Birds of America, with an approximate value of $\$ 240,000$. His method was simply to hide in the institution after it had closed and then leisurely proceed to steal the items he desired. Investigation by the FBI assisted in locating the items in a foreign country, and they were returned to the rightful owner.
On another occasion a lawyer was found to have a valuable Picasso in a portfolio also containing his own prints. The subject had asked an employee of the institution to be allowed to compare his prints with the artist's original and, when unobserved, he attempted to steal the original. Subsequent investigation uncovered a large quantity of prints which had been stolen from numerous museums and art galleries.

Unfortunately, employees of libraries and archives are not themselves immune from the temptation of removing items for sale to legitimate businessmen dealing in historical documents. In fact, collectors are partly responsible for some thefts in an indirect way because they have the funds necessary to invest and, therefore, create a market for stolen historical records, manuscripts, and books.

In one particular instance of employee theft, investigation by the FBI resulted in recovery of thirty-four items with a value of more than $\$ 11,000$ which had been stolen from an eastern historical society. In another, an employee stole from a collector several rare books valued at more than $\$ 18,000$. FBI investigation recovered all of the stolen books, and the thief received a prison sentence.

In another recent case a rare 1855 edition of a Walt Whitman book was stolen by a thief who substituted an excellent facsimile for it. This switching went undetected for a period of time. However, in that investigation, the records kept by the victim institution allowed the FBI to locate valuable evidence.

A large number of valuable atlases were stolen from a major university's collection, and the method of theft was quite ordinary. The thief simply took the books from the stack, concealed them under his coat, and walked out of the library without being stopped. On other occasions this individual simply waited until persons responsible for 
safeguarding the rare books were preoccupied with other activities, and then he left, carrying the books in his arms. In this case, FBI investigation resulted in the recovery of 130 books stolen from various universities throughout the country.

Several years ago a university library relinquished sets of scientific periodicals valued at $\$ 15,000$ to a person representing himself as an official in a company wishing to microfilm the material. However, the man simply sold the periodicals. Investigation revealed numerous similar thefts from various libraries. FBI efforts resulted in recovery of these periodicals, and the thief received a two-year sentence.

A recent investigation dealt with the theft of valuable books from a western university. The thief "laundered" the stolen items by removing ownership information, replacing book pages, and, in some instances, ironing out embossing stamps on particular pages. As a subterfuge, this thief would trade stolen books for other rare books with various collectors. Thereafter, he sold the legitimate books to dealers, whereas the collectors unknowingly held stolen rare books.

\section{LESSONS LEARNED}

What then can be learned from these thefts? First, there is the realization that an active market exists for valuable library and archival materials. Second, the limited scope of the market suggests prompt dissemination of information about the theft to interested persons in the profession as well as to established dealers and collectors can help in recovery. Such persons may learn of the stolen materials, and with their cooperation law enforcement agencies can do their job. Last, libraries must be constantly vigilant and consider their security procedures as necessary elements in their programs.

In summary then, librarians should know their valuable items, prevent their loss if possible, conduct regular inventories, promptly report losses, and be able to properly identify specific stolen items. 